\title{
Fabrication Dye Sensitized Solar Cells (DSSCs) Using $\beta$-Carotene Pigment Based Natural Dye.
}

\author{
Wa Ode Nirwana Sari Halidun ${ }^{1}$, Eka Cahya Prima ${ }^{1,3}$, Brian Yuliarto $^{1,2, *}$, and Suyatman ${ }^{1}$ \\ ${ }^{1}$ Advanced Functional Materials Laboratory, Departement of Engineering Physics, Faculty of \\ Industrial Technology, Institut Teknologi Bandung, Bandung 40132, Indonesia \\ ${ }^{2}$ Research Center for Nanoscience and Nanotechnology (NRCN), Institut Teknologi Bandung, \\ Bandung 40132, Indonesia \\ ${ }^{3}$ Science Laboratory, Departement of Science Education, Fakultas Pendidikan dan Ilmu Pengetahuan \\ Alam, Universitas Pendidikan Indonesia, Bandung 40154, Indonesia
}

\begin{abstract}
The adsorption characteristic of natural dye has been studied on harvesting light using purification process. The purification process used for separation pigment photosynthesis of syngonium leafs was called fractionation. The first fractionation of the dye contains pigment of $\beta$ carotene. The absorpton spectrum of $\beta$-carotene has been investigated by using Uv-Vis spectroscopy. The Fourier Transform Infrared revealed that the binding of the dye was on the surface of $\mathrm{TiO}_{2}$. Analysis absorbance and energy gap of the dye has been investigated by using Uv-Vis spectroscopy and Tauc relation. The cells were illuminated under $100 \mathrm{~mW} / \mathrm{cm}^{2} \mathrm{AM} 1.5$ condition. The performance of the cells with sensitized the fractionation dye has a short circut current density $\left(\mathrm{J}_{\mathrm{sc}}\right)$ of $0.27 \mathrm{~mA} / \mathrm{cm}^{2}$, an open circuit photovoltage $\left(\mathrm{V}_{\mathrm{oc}}\right)$ of $0.4 \mathrm{~V}$, and Fill Factor $(\mathrm{FF})$ of $68.89 \%$. Furthermore, the overall efficiency of DSSC is $0.074 \%$. The low efficiency for the fractionation cell based dye sensitized solar cells due to the weakness of interaction between dye molecule and the surface of $\mathrm{TiO}_{2}$.
\end{abstract}

\section{Introduction}

Dye sensitized solar cells (DSSCs) is the third generation of photovoltaic device that attracted considerable attention due to the low cost fabrication, enviromental friendly and simple fabrication [1]. The first concept of DSSCs was introduced by Grätzell and his coworker in the year 1991 [2]. The device can convert the light energy into electrical energy by using sensitizer. The sensitizer can absorb visible light and then inject an electron to the semiconductor to generate photocurrent.

The process of photosensitization of the dye on the surface of semiconductor has an important role to increase the performace of DSSCs. The photosensitization is the process of harvesting light and electron injection of the dye from low level energy to the conduction band of semiconductor [3]. Thus, the efficiency of DSSC is mainly determained by the using of sensitizer.

* Corresponding author: brian@tt.itb.ac.id 
Generally, transition metal coordination compound such as ruthenium transition metal polypyridyl complex is used as an effective sensitizer. The highest efficiency of DSSC using ruthenium complex is $11-12 \%$ [4]. Although, the ruthenium has given the best performance as sensitizer, ruthenium polypyridyl contains heavy metals, which makes this kind of sensitizer unfriendly for the enviroment, and limited in amount. Moreover, the synthesis of this complex is very complicated and expensive [5]. In order to replace the rare and expensive ruthenium material, the natural dye from pigment of leaf, seed, and fruit can be used as a low cost, easy extraction and friendly enviroment sensitizer.

Photosyntetic pigments that commonly consists of chlorophyll, and its derivative, and carotenoid, have an important role in harvesting light and electron transport. Those pigment contain carboxylate group that influence photosensitization process on the surface $\mathrm{TiO}_{2}$.

In this work, pigment $\beta$-carotene from syngonium $s p$ has been separated by using column chromatography technique. The $\beta$-carotene pigment extract from Syngonium $s p$ was used as natural dye in DSSC. The absorption spectrum, the band gap analysis, and the interaction of the dye onto surface of $\mathrm{TiO}_{2}$ have been investigated by using Uv-vis spectroscopy, Tauc relation and FTIR spectroscopy, respectively.

\section{Experimental}

\subsection{Preparation of Natural dye solution}

Syngonium $s p$ was washed, crushed in a small pieces and dried in room temperature over night. The leaf was blended to obtain powder of Syngonium sp. Then, the pigment of Syngonium $s p$ was extracted by using maserasi method. The leaf was immersed in acetone solutian with ratio at $1: 5(\mathrm{v} / \mathrm{v})$.

Separation of $\beta$-carotene pigment in the Syngonium $s p$ is performed using column chromatography tecnique. The technique follows the procedure of Shioi [6]. The $\beta$-carotene pigment in the purification process has been obtained from the first fractionation. The Fig.1 shows the result of the first fractionations (F1) from Syngonium sp. The F1 dye will be used as natural photosensitizer for this work as natural dye.

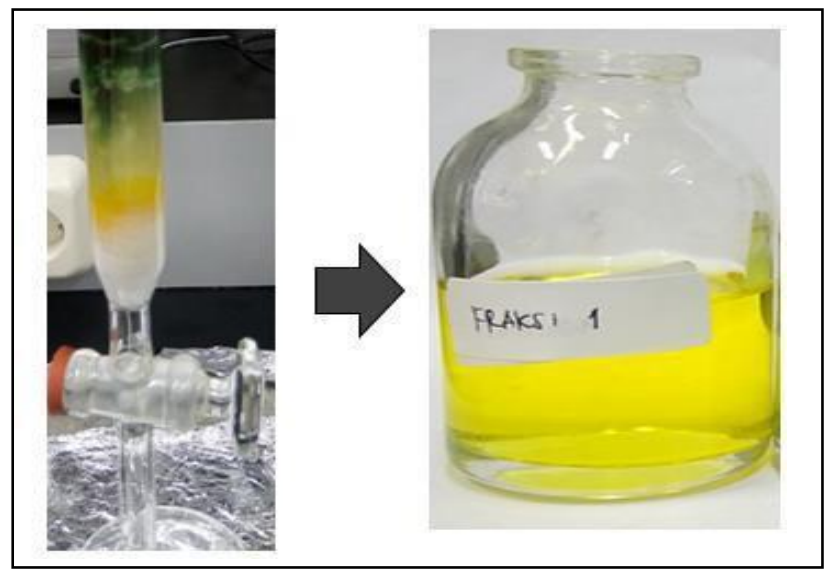

Fig.1 The first fractionation pigment from Syngonium $s p$ 


\subsection{Preparation of dye sensitized solar cells}

Thin film semiconductor $\mathrm{TiO}_{2}$ and the counter electrode, Pt, were coated onto FTO glass substrate that obtained from dyesol. These electrode were washed by using isopropil alcohol solution. Semiconductor $\mathrm{TiO}_{2}$ was immersed into $0,1 \mathrm{M}$ dye solution for 3 days. Then, $\mathrm{TiO}_{2}$ that was sensitized dye, was rinsed by using ethanol solution.

$\mathrm{TiO}_{2}$ sensitized dye photoelectrode and Pt counter electrode were assembled by using suryline polymer that followed the procedure of Prima [7]. The electrolyte solution, EL

HSE, that obtained from Dyesol was dropped into the hole of counter electrode and then the hole was sealed by another suryline to prevent electrolyte leakage.

\subsection{Characterization and Measurement of dye sensitized solar cells.}

To investigate physical properties of natural dyes, the dye of Syngonium sp absorption spectrum was investigated by using Uvi-visible spectroscopy of Hewlett Packard 8453 Agilent Technologies. The binding vibration of dye solution and $\mathrm{TiO}_{2}$ photoelectroda, after and before immersed in dye solution, were investigated by using Fourier Tranform Infrared spectroscopy of Prestige 21 Shimadzu Japan. To calculate energy gap of dye solution was investigated by using Tauc realation, as given Eq.(1) [8].

$$
\begin{gathered}
\alpha h v \approx\left(h v-E_{g}\right) \\
\mathrm{FF}=\mathrm{V}_{\max } \times \mathrm{I}_{\max } / \mathrm{V}_{\mathrm{oc}} \times \mathrm{I}_{\mathrm{sc}} \\
\eta=\mathrm{V}_{\mathrm{oc}} \times \mathrm{I}_{\mathrm{sc}} \times \mathrm{FF} / \mathrm{P}_{\mathrm{in}}
\end{gathered}
$$

To investigate performance of dye sensitized solar cells, the device was iluminated under standard solar simulator $\left(\mathrm{AM} 1.5 ; 1000 \mathrm{~mW} / \mathrm{cm}^{2}\right)$. The photocurrent- voltage $(\mathrm{J}-\mathrm{V})$ curve was used to determine the short-circuit photocurent $\left(\mathrm{J}_{\mathrm{sc}}\right)$ and open-circuit voltage $\left(\mathrm{V}_{\mathrm{oc}}\right)$. The Eq.(2) was used to calculate the Fill Factor (FF). The overall efifciency of DSSC has been observed by using Eq.(3).

\section{Results and Discussion}

\subsection{Uv-vis Spectroscopy}

The uvi-vis absorption spectra of F1 dye was shown in Fig.2. According to the Fig.2, the absorption peaks of F1 dye was observed between $414 \mathrm{~nm}$ and $502 \mathrm{~nm}$ that confirmed as carotene pigment that indicated transition energy from $S_{0}$ to $S_{1}$ [9-13]. The $\beta$-carotene pigment is the part of the carotene pigment that mainly obtained in the leaf that have absorption characterization of $440-480 \mathrm{~nm}$ [14]. It corresponds to the results that was showed in Fig.2. 


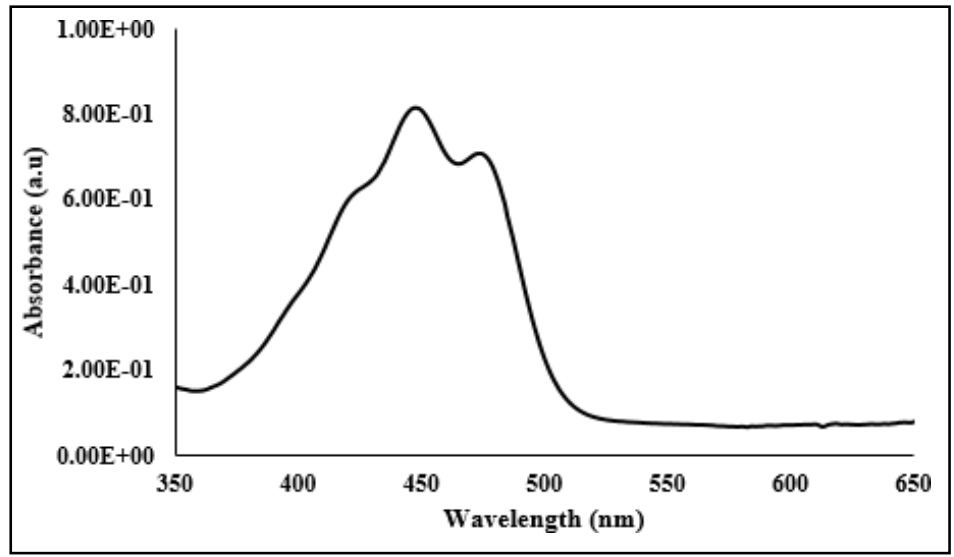

Fig 2. The absorption spectrum of The $\beta$-carotene pigment.

\subsection{Determination Gap Energy of Natural Dye from pigment Syngonium sp.}

The gap energy of each pigment can be evaluated by using Tauc relation that is described on Eq.1. Fig. 3 shown the plot of hv versus $(\alpha h v)^{2}$ for $\beta$-carotene dye. The gap energy of $\beta$ carotene based natural dye is $2.47 \mathrm{eV}$.

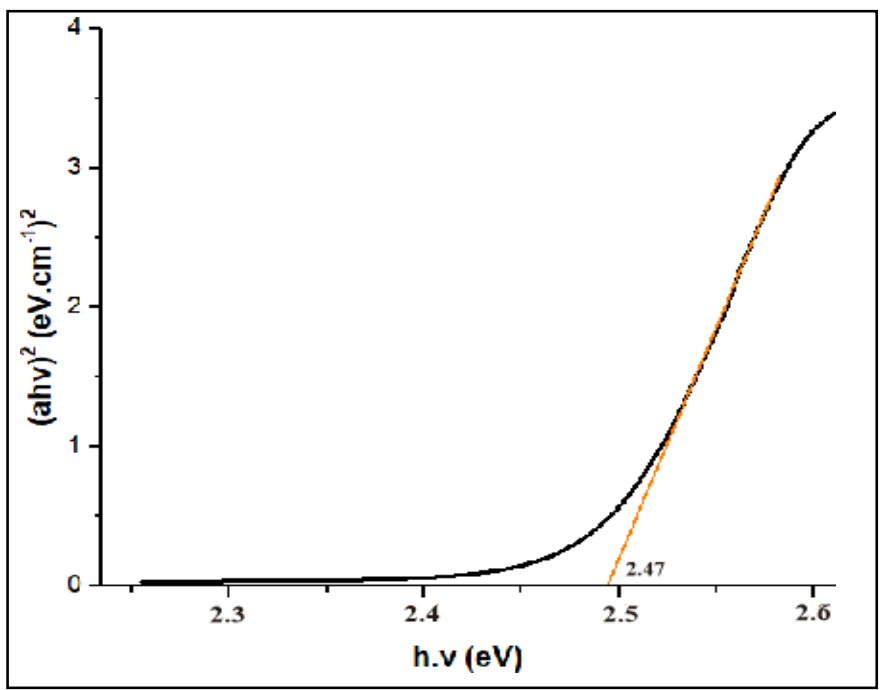

Fig.3 Determmination of gap energy using Plot Tauc relation

\subsection{The Fourier Transform Infrared (FTIR) Characterization}

Fig.4 shows the fourier transform infrared of $\mathrm{TiO}_{2}$ before and after soaking in dye solution. According to the Fig.4, the peaks of $\mathrm{TiO}_{2}$ presented at $3429.53 \mathrm{~cm}^{-1}$ is affected by O-H stretching vibration bonding of hydrogen water molecule. The peak shown at $1625.21 \mathrm{~cm}^{-1}$ is assigned to $\mathrm{O}-\mathrm{H}$ bending, and the peak at $454.3 \mathrm{~cm}^{-1}$ is due to the vibration bonding of Ti$\mathrm{O}$ [15]. After $\mathrm{TiO}_{2}$ was immersed in dye solution, it appeared two new peaks at $2917.3 \mathrm{~cm}^{-1}$ and $2846.6 \mathrm{~cm}^{-1}$, both of peaks were confirmed as peak of natural dye that bond onto surface $\mathrm{TiO}_{2}$. 


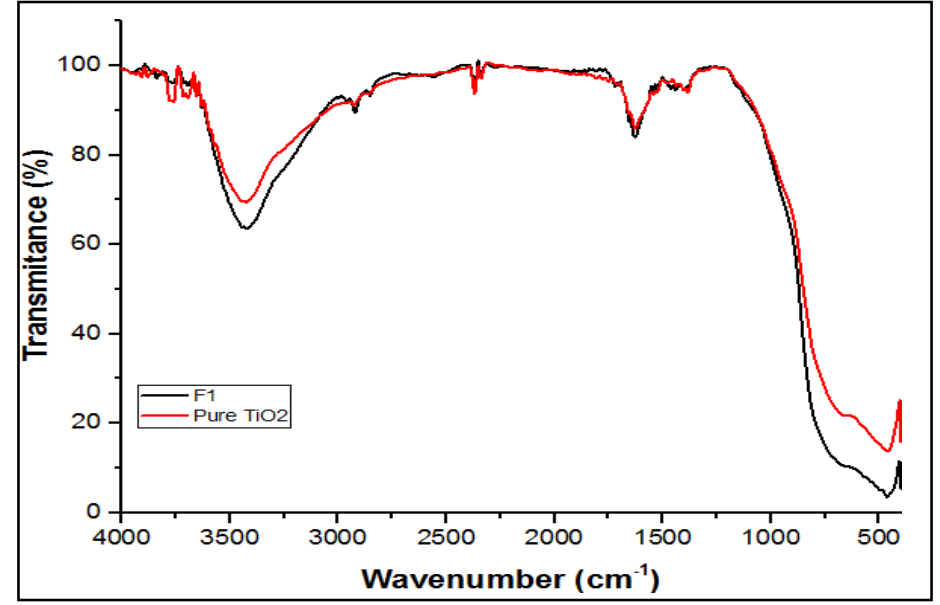

Fig.4 The Fourier Transform Infrared of $\mathrm{TiO}_{2}$ before and after immersed into dye Solution

\subsection{The Performance of Dye Sensitized Solar Cells}

The performance natural dye from pigment photosynthesis of $\beta$-carotene was performed by measuring the current density-voltage $(\mathrm{J}-\mathrm{V})$ under illumination $100 \mathrm{mw} / \mathrm{m}^{2} \mathrm{AM}, 1.5$ standard. The parameter of short circuit current density $\left(\mathrm{J}_{\mathrm{sc}}\right)$, open circuit voltage $\left(\mathrm{V}_{\mathrm{oc}}\right)$, fill factor (FF), and efficiency ( $\eta$ ) were listed in Table 1.

Table 1 Parameter performance natural dye using natural pigment of $\beta$-carotene from syngonium $s p$.

\begin{tabular}{|c|c|c|c|c|}
\hline $\begin{array}{c}\text { Natural } \\
\text { Dye }\end{array}$ & $\begin{array}{c}\mathrm{J}_{\text {sc }} \\
\left(\mathrm{mA} / \mathrm{cm}^{2}\right)\end{array}$ & $\begin{array}{c}\mathrm{V}_{\text {oc }} \\
(\mathrm{V})\end{array}$ & $\begin{array}{c}\mathrm{FF} \\
(\%)\end{array}$ & $\begin{array}{c}\eta \\
(\%)\end{array}$ \\
\hline $\mathrm{F} 1$ & 0.27 & 0.4 & 68.89 & 0.074 \\
\hline
\end{tabular}

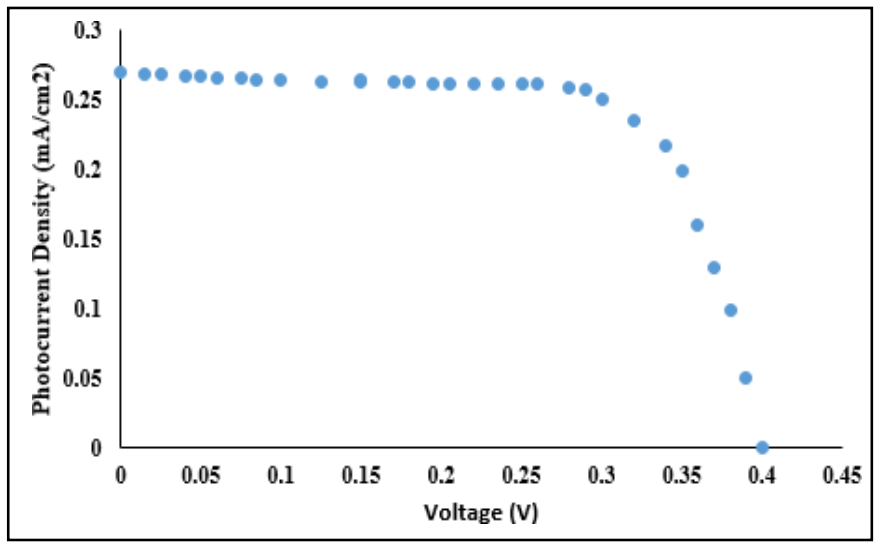

Fig.5 The current - voltage curve for F1 dye based DSSC

The Fig.5 shown the J-V curve of $\beta$-carotene pigment based natural dye of DSSC. The low efficiency $(\eta)$ was probably influenced by some factors such as the concentration of dye was low, the gap energy of dye was wide and the absorption of dye in visible light spectrum 
was limited. Therefore, they cause the weakness of interaction between dye molecule and the surface of $\mathrm{TiO}_{2}$.

\section{Conclusion}

Natural dye from natural pigment photosynthesis such as $\beta$-carotene from the leaf of syngonium $s p$ through the purfication process can be used as natural photosensitizer in DSSC because it is ability to harvest light in visible spectrum. Moreover, the performance $\beta$ carotene based natural dye DSSC is still low. It is caused by the concentration and the limited harvesting visible light of the dye is low due to the low of photosensitization prosess between dye and the surface of semiconductor $\mathrm{TiO}_{2}$.

This research was supported by Advance Functional Material Laboratory (AFM), Bandung Institute of Technology (ITB) and funded by Indonesia Endowment Fund for Education (Lembaga Pengelola Dana Pendidikan (LPDP), Indonesia).

\section{References}

1. S. Shalini, R.B. Prabhu, S. Prasanna, S.P. Mallick, S. Senthilarasu. Spectrochimica Acta A: Molecular and Biomolecular Spectroscopy 148 (2015).

2. B. O'Reagen, M. Grätzel. Nature 353 (1991)

3. J. Spikes. Photosensitization. In: Andery Lim.,et al. Spectrochimica Acta Part A; Molekular and Biomolecular Spectroscopy 138 (2015)

4. H. Zhou, L. Wu, Y. Gao, T. Ma. Chemistry 219 (2012)

5. H. Chang, H.M. Wu, T.L. Chen, K.D. Huang, C.S. Jwo, Y.J. Lo. Alloys and Compounds 495 (2010)

6. Y. Shioi. Biochemistry, Biophysics, Function and Aplication, pp. 123-133 (2006)

7. E.C. Prima, N. N. Hidayat, B. Yuliarto, Suyatman, H.K. Dipojono. Spectrochimica Acta A: Molecular and Biomolecular Spectroscopy 171 (2017).

8. J. Tauc. Mat. Ress. Bull, Vol. 3, pp. 37 - 48 (1968)

9. G. Calogero, A. Bartolotta, G.D. Marco. DOI 10.1039/c4cs00309h .

10. E. Yamazaki, M. Murayama, N. Nishikawa, N. Hashimoto, M. Shoyama. Solar Energy 81 (20017)

11. N.M. Gomez-ortiz, I.A. Vazquez-Maldonado. A.R. Perez-Ezpadas, G.J. Menarejon, J.A. Azamar-Barrios, Oskam. Solar Energy Materiar and Soar Cells 94 (2010).

12. S. Hao, J. Wu. Y. Huang, J. Lin. Solar energy 80 (2006)

13. K.V. Helmalata, S.N. Karthick, C. Justin Raj, N.Y. Hong, S.K. Kim, H.J. Kim,. Spectrochimica Acta A: Molecular and Biomolecular Spectroscopy 96 (2012)

14. X.F. Wang, A. Matsuda, Y. Koyama, H. Nagae, S. Sasaki, H. Tamiaki, Y. Wada. Chemical Physics Letter 423 (2006).

15. S. Ananth, P.Vivek, T. Arumanayagam, P. Murugakoothan. Spectrochimica Acta A: Molecular and Biomolecular Spectroscopy 128 (2015) 